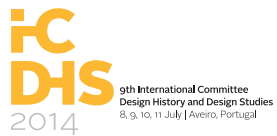

Blucher Design Proceedings

Dezembro de 2014, Número 5, Volume 1

Anders V. Munch

University of Southern Denmark

Danish representative of Nordic Forum of Design History

\title{
Putting your self in the centre? A short essay on Danish inventions
}

'To be modern is nothing new to us' could be said to be a recurrent reaction among Danish designers and critics throughout the 2oth century. The receptions of modern, foreign impulses like art nouveau, functionalism and beyond have been followed by different sketches of age-old tradition to explain how Denmark could resist, temper or naturalize incoming styles. I will present some of these reactions and the understandings of tradition behind them. We can discuss how these reactions places Danish design in relation to the centres of historical development. As an autonomous centre itself, as a voluntarily chosen periphery or even as a pure and sound province - produced by self-exoticization? While the other Nordic countries often have seen Denmark as their bridgehead to the European continent, Danes have at some points seen their role as being a dike or bulwark to the tides of arbitrary fashions or uncultivated modernity. Some reasons for this lies of course in differences in geo-political positions. Even the most international Danish designer as Arne Jacobsen or Poul Kjærholm are thought to have 'grounded' their impulses from Eames and Mies van der Rohe in local traditions of materiality and usability. I will not discuss these examples, but present different expressions of this understanding. There have been some research into the foreign reception of the Nordic countries at international exhibitions, see especially Ingeborg Glambek '”Nordic Form' as seen from the outside", 2009, but little systematic research on the reverse Danish receptions. And this might be a result of this self-understanding.

At the Paris World Exhibition in 1900 the Museum of Decorative Arts (now Designmuseum Denmark) in Copenhagen bought quite a lot of items to the fairly new collections. But the librarian and later director of the museum, the art historian Emil Hannover, wrote elaborated reflections on this 'rise of the new style', and how Denmark related and reacted to it, in his 30 pages review of the exhibition in the Danish 'Journal of Industry'. He follows, how the style flushed from Great Britain over the Netherlands 
to France and Germany and changed to a fashionable tidal wave. It threatens to flood Denmark, but Hannover believes that Danish arts and crafts are so sound and grounded in a no-nonsense tradition that will show resistant to fashion. At the European main land the new style has risen to a movement and a project, but this do not exist in Denmark: "There is in Denmark no common effort showing up in direction of style; the new style has until this day not gained any footing in our country and will hardly be able to do so in the future." (Hannover 1900:206) The reasons, he states for this, is the character of 'inner truth and genuineness' and a strong interest in artistic personality that goes against copying trends. This is, of course, not true, if we look at the actual form giving around 1900.

The critique of art nouveau and especially German Jugendstil for being too fashionled and volatile is common, but Hannover goes very far to insure resistance in claiming Danish arts and crafts to be free from any style at all. This was radical in the years where speculations in the notion of style were so productive to art history and modern designers (Munch 2005). And so contrary to the situation of the Finns at the very same exhibition, where they were praised for their redesigned Karelian style! (Korvenmaa 2009) Architectural historian Barbara Miller Lane has noticed widespread, Scandinavian discussions of art nouveau in her comparison with Germany in the same period. "Discussions of the influence of art nouveau, more numerous in the Scandinavian countries than in Germany, help to stress the newness of architecture and design from around 1900 and permit Scandinavian scholars to underline the importance of French art and culture for the development of modernism in their own countries" (Miller Lane 2000:13). This holds only true for Denmark as a far as, it was more convenient to admit artistic inspiration from France than from Germany. But only as late as 1907 the Danish term 'Skønvirke' was introduced to signify the new direction of thing that was clear from around 1890 among Danish artists. And the word in its literal meaning, 'the working of beauty', refers in rather the activity of arts and crafts than the style (Gelfer-Jørgensen 2004).

As late as 1918 Hannover insists that Denmark and the rest of the Nordic countries went free of the modern German style. "For the most important untouched by the modern, German style the Nordic, though, took active part in the general rise of architecture and decorative arts" (Hannover 1918:282). This is a recognition of the cultural and societal benefits of the Kunstgewerbe-movement and especially Werkbund that Nordic artists and producers have made to their own project, not an accept of stylistic influence. The authenticity of Danish values and creations are still untouched. This holds for the different reviews of Werkbund-exhibitions in Denmark that don't see anything in the Werkbundart works or products shown, but stresses the ideal and organisation of the German movement as worth matching in Denmark, especially texts the architect Carl Brummer, who had been Danish representative at the Werkbund congress, Cologne 1914. The books on Werkbund by the Swedish art historian Gregor Paulsson were also important to this Danish accept of influence. This opening might be interpretated as a match in values and cultural ideals, which Miller Lane could sketch out, or just a seldom political realism at the end of the First World War, where the competition between nation-brands should start up 
again with economic and cultural weapons, rather than military.

The Danish receptions of the international movement of functionalism followed some of the same lines. The architect Kaare Klint that founded the school of furniture art took the Bauhaus-ideas as a confirmation of his own work that stripped traditional types of furniture and proportioned them according to the measures of the human body and standard utensils. A geometric style, new materials and alternative constructions, though, were only introduced much later by some of his pupils. The school was rather an artistic revitalisation of the cabinetmakers and carpenters trade and a reinterpretation of the 19th century tradition of artist's furniture in Denmark as a distillation of pure and functional forms. Another modern designer, Poul Henningsen, got rapid, international fame for his lamps used by both Mies van der Rohe and Aalto and had a more radical reception of the political ideals and means of mass production. But in his critical writings, though, he had long reflection on, how Le Corbusier and Bauhaus went to far in the actual forms and turned steel tubes, flat roofs and glass walls into just another fashion beyond functional justification. In "Tradition and modernism" from 1927 he states that a radical modernist creating a new style ex nihilo is just as far off as the traditionalist reproducing dead forms blocking modern forms of living. Both are out of contact with a living, historical development. "The important part of the tradition is about development of types. When generation after generation have solved the same problem (with the same content), then the result will with necessity become more and more harmonious and splendid: a type will appear" (Henningsen 1927:9). Though he worked himself with a new task, the electrical light, using new materials and technology, he uses most of this 30 pages article to state that most designs ought to keep with traditionally developed forms and materials. New forms are only allowed by solving new problems.

Most demonstratively is perhaps the turn in Danish architecture in the 1930 s to 'Functional tradition', where international functionalism was moderated with brick walls and steep roofs. The academy professor Kay Fisker explained it in 1943 as going back to a mid-19th century development of suburban brick houses by a historicist architect, J.D. Herholdt. "As so often has happened, the foreign impression has in [Herholdt] been transformed and adjusted our conditions; his architecture has been emancipated and is in fact totally different from the latin, architectural ideal" (Fisker 1943:1). Despite Venetian or Neo-Gothic motives these houses was pointed out as proofs of sound adjustments to climate, local materials and care of details and craftsmanship, the beginning of a Danish tradition in single family housing.

In design the most insisting demarcation of a Danish tradition is another academy professor Steen Eiler Rasmussen, who in 1960 denies any substantial influence from Bauhaus because of the modest focus on usability and quality. "You can see these tendencies as natural in a small, strongly populated country, where you have to spare what you got, where you have to subdivide and refine, where economy and considerations of use still have to come in first line" (Rasmussen 1960:148). Once again this understanding of 'Danish virtues' are defended against the vices of modernity. "But beside all the fashionable and effect seeking will there not still, though, be a need for the modest 
Danish object which is thoroughly worked out, made to last and to serve as a good and solid tool?" (loc.cit) The Danish designers and architects felt that the success of Danish furniture, Scandinavian Design and Nordic functionalist architecture was a reward of their fidelity to this tradition of modest virtues. But the questions are of course, whether these traditions are sketched rather as wishful ideals to counter foreign competition, and to which degree such virtues can be visible in the design objects themselves at all? The critique of fashion and pure style is very well known throughout modernist design discourse, but the rhetoric of Danish designers has been very insisting to resist any commensurability to international design. And this self-exoticization has at some points been a very effective promotion.

.. but we are searching after the lost thread, and do we find it, we tie a new tradition so firmly that even the rhubarb-architects will build with taste, because they know nothing else. (Jensen-Klint 1911:10)

\section{References}

Carl Brummer, Er vi forberedt?, København: Berlingske Tidendes Officin 1918

Kay Fisker, Omkring Herholdt. Betragtninger over nordisk arkitekturtradition, offprint of Arkitekten 1943

Mirjam Gelfer-Jørgensen, "Skønvirke. A short Essay on National Aspects in spplied Art around 1900", Scandinavian Journal of Design History vol. 14, 2004, pp.72-82

Glambek, Ingeborg, "'Nordic Form' as seen from the Outside. The interpretation of Nordic design and architecture outside the region", in Caroline Spliid Høgsbro (ed.), Nortopia. Nordic Modern Architecture and Postwar Germany, Berlin: jovis Verlag 2009 Emil Hannover, "Rundskue over Europas Kunsthaandværk paa Verdensudstillingen", in Tidsskrift for Industri, August 1900

Emil Hannover, Det nittende Aarhundredes Kunst, København 1918

Poul Henningsen,"Tradition og Modernisme" (1927), appendix in Tradition og modernisme, ed. Bay \& Jensen, Odense: Syddansk Universitetsforlag 2008

P.V. Jensen-Klint, Bygmesterskolen, Copenhagen 1911

Pekka Korvenmaa, Finnish Design: A concise history, Helsinki: University of Art and Design 2009

Barbara Miller Lane, National Romanticism and Modern Architecture, Cambridge 2000 Anders V. Munch, "Heraus aus den goldenen Rahmen", in Johan Rohde, ed. Gertrud Oelsner \& Gertrud Hvidberg-Hansen, Berlin: Bröhan 2006 Anders V. Munch, Der stillose Stil. Adolf Loos, Munich: Fink 2005 Steen Eiler Rasmussen, "Bauhaus og den danske brugskunst", Dansk Kunsthaandværk 1960, pp. 142-49 